JURNAL SOSIAL-EKONOMI PERTANIAN DAN AGRIBISNIS

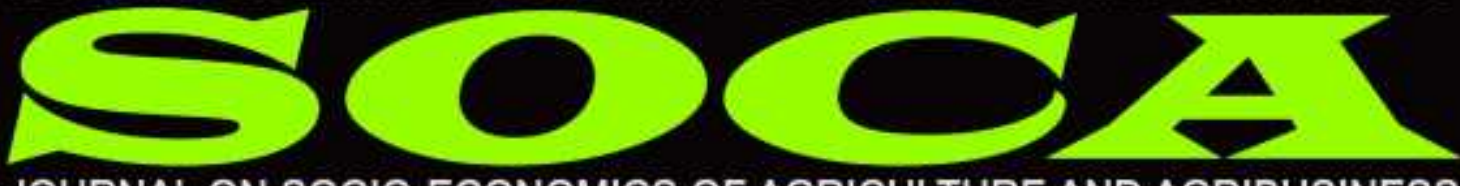

JOURNAL ON SOCIO-ECONOMICS OF AGRICULTURE AND AGRIBUSINESS

e-ISSN: 2615-6628

p-ISSN: $1411-7176$

\title{
PEMBERDAYAAN MASYARAKAT DESA MELALUI PROGRAM INTEGRATED ECOFARIMING \\ (Studi Kasus di Desa Asinan Kecamatan Bawen Kabupaten Semarang)
}

\begin{abstract}
Siti Farikhah ${ }^{1}$, Nurul Fatimah², Asma Luthfi ${ }^{3}$
${ }^{1}$ Pegiat Masyarakat Desa di Kabupaten Batang, 2,3Dosen Jurusan Sosiologi dan Antropologi, Fakultas Ilmu Sosial, Universitas Negeri Semarang sitifarikhah9@gmail.com, fatimahnurul8@mail.unnes.ac.id, asma_luthfi@mail.unnes.ac.id
\end{abstract}

\begin{abstract}
ABSTRAK
Potensi lahan pertanian yang cukup luas di Desa Asinan yang selama ini diolah dengan menggunakan pupuk kimiawi mendapatkan perhatian oleh Bank Indonesia wilayah Jawa Tengah untuk dijadikan sebagai Desa Binaan. Melalui Desa binaan ini, Bank Indonesia memberikan program pemberdayaan masyarakat pertanian yang diintegrasikan dengan peternakan yang dikenal dengan istilah integrated ecofarming. Penelitian ini menggunakan metode kualitatif. Hasil penelitian menunjukkan bahwa (1) Pelaksanaan program integrated ecofarming di Desa Asinan dapat dikatakan bahwa program tersebut gagal karena tidak berkelanjutan, (2) Hambatan dalam program integrated ecofarming antara lain pola pemanfaatan dan pengusaan lahan para petani menggunakan sistem maro dan sistem sewa, sistem irigasi yang masih menggantungkan pada alam, kurangnya pasokan pupuk organik, kebiasaan dan maindset petani yang tidak mudah dirubah karena terbiasa menggunakan pupuk kimia, sarana dan prasarana yang kurang dimaksimalkan, pemasaran produk yang susah karena beras belum tersertifikasi organik, (3) Partisipasi masyarakat dilihat dari partisipasi pengambilan keputusan, partisipasi dalam pelaksanaan, pengambilan manfaat, partisipasi dalam evaluasi serta dalam analisis Longwe partisipasi masyarakat Desa Asinan termasuk kedalam kriteria kesejahteraan.
\end{abstract}

Kata kunci: Bank Indonesia, Integrated Ecofarming, Partisipasi, Pemberdayaan Masyarakat.

\section{EMPOWERMENT OF VILLAGE COMMUNITIES THROUGH INTEGRATED ECOFARMING PROGRAMS \\ (Case Study in Asinan Village, Bawen District, Semarang Regency)}

\author{
ABSTRACT \\ The vast potential of agricultural land in Asinan Village, which has been \\ processed using chemical fertilizers, has received attention from Bank Indonesia in


the Central Java region to become a Development Village. Through this assisted village, Bank Indonesia provides an agricultural community empowerment program that is integrated with livestock known as integrated ecofarming. This study uses a qualitative method. The results showed that (1) Implementation of the integrated ecofarming program in Desa Asinan can be said that the program failed because it was unsustainable, (2) Obstacles in the integrated ecofarming program include land use and management patterns of farmers using the maro system and rental systems, irrigation systems which still depends on nature, lack of supply of organic fertilizers, habits and mindsets of farmers who are not easily changed because they are accustomed to using chemical fertilizers, facilities and infrastructure that are not maximized, product marketing is difficult because rice has not been certified organic, (3) Community participation seen from participation decision making, participation in implementation, benefit taking, participation in evaluations and in Longwe's analysis the participation of the Asinan Village community is included in the welfare criteria.

Keywords: Bank Indonesia, Integrated Ecofarming, Participation, Community Empowerment.

\section{PENDAHULUAN}

Masyarakat desa di Indonesia sebagian besar masih bersifat homogen dengan sistem kekeluargaan yang kuat, dan ketergantungan pada alam yang masih tinggi. Dalam hal ini, petanian merupakan aspek yang paling banyak digeluti oleh masyarakat pedesaan di Indonesia yang secara geografis dikalisifikasikan menjadi sistem pertanian dataran tinggi dan sistem pertanian dataran rendah. Kedua sistem pertanian ini mempunyai karakteristik, jenis tanaman pertanian, irigasi, model dan teknik yang berbeda-beda. (Gandi, 2017). Sistem pertanian dataran tinggi biasanya dikenal juga dengan istilah pertanian lahan kering. Hal ini disebabkan jenis tanaman yang diproduksi adalah tanaman tahunan yang tidak memerlukan asupan air yang banyak. Di Jawa Tengah, karakteristik pertanian lahan kering ini dapat dijumpai pada perkebunan skala besar seperti jati, kopi, dan karet, baik yang dikelola oleh masyarakat maupun korporasi swasta dan pemeritah seperti perhutani dan PTPN (Luthfi, 2010).

Sementara itu, sistem pertanian dataran rendah umumnya berupa lahan persawahan yang teknik budi dayanya membutuhkan asupan air yang cukup. Saat ini, kondisi di pedesaan masih banyak terdapat sawah-sawah yang terhampar luas. Namun sawah-sawah tersebut dikerjakan oleh petani yang sudah berusia tua, dan sedikit usia muda yang mengerjakan sawah dan bekerja sebagai petani. Berkurangnya minat para pemuda dalam bidang pertanian, dapat disebabkan adanya anggapan bahwa pekerjaan di bidang pertanian suatu pekerjaan yang bergengsi. Kondisi menyebabkan para pemuda beranggapan bahwa mereka akan ketinggalan zaman jika masih tetap bekerja di sektor pertanian (Fatimah, 2009).

Selain kekurangan tenaga kerja muda, pertanian di desa juga tidak berkembang karena kurangnya inovasi yang bisa meningkatkan produktivitas dan kualitas produk pertanian. Sejak program revolusi 
hijau digalakkan oleh Pemerintah Orde Baru sekitar tahun 1980an, tercatat ada banyak program pertanian yang digalakkan oleh pemerintah. Hanya saja, pendekataan yang dipergunakan saat itu masih bersifat top down. Hal ini yang membuat masyarakat hanya menjadi sasaran dari program demi kepentingan swasembada pangan. Namun seiring perubahan orientasi pembangunan secara umum, pembanguan di bidang pertanian saat ini juga mengalami pergeseran paradigma yang saat ini lebih menekankan pada aspek pemberdayaan masyarakat.

Program pemberdayaan yang digalakkan diawali dengan pembentukan kesadaran kritis dan peningkatan partisipasi masyarakat. Begitupun halnya pemberdayaan di bidang pertanian diarahkan untuk mewujudkan masyarakat yang mandiri dan berdaya. Dalam hal ini. model pendekatan ke masyarakat dilakukan dengan menggeser pola top down menjadi pola bottom up yang menempatkan masyarakat sebagai pelaku aktif dalam pembangunan. Pendekatan ini dikenal dengan pembangunan manusia yang dilaksanakan secara sinergis dari berbagai stakeholder yakni pemerintah, swasta dan masyarakat. Program-program di dalamnya mencoba mengkoneksikan antara kepentingan pemerintah dan kebutuhan masyarakat. Selain itu, keterlibatan pihak swasta juga diharapkan dapat berkembang melalui program-program yang mereka tawarkan (Luthfi,2013).

Agar masyarakat menjadi mandiri dan sejahtera, maka dibutuhkan program-program yang berbasis masyarakat yang berkelanjutan sebagai bagian dari proses pembinaan dan pengembangan pertanian di desa. Model pengembangan petanian di desa dapat disesuaikan dengan potensi, masalah, dan kebutuhan pada desa tersebut. Model pengembangan desa yang inovatif mensyaratkan pentingnya komunikasi dan peran tidak hanya penyelenggara pemerintahan di tingkat desa (Kades dan Badan Permusyawaratan Desa), tetapi juga elemen masyarakat lain khususnya pemuda dan kelompok UKM yang mendominasi kegiatan perekonomian. Peran stakeholder lain yang sama pentingnya adalah sinergitas antar Satuan Kerja Perangkat Daerah (SKPD) di lingkungan Pemkab, dan peran perguruan tinggi dalam bentuk penelitian dan pengabdian kepada masyarakat (Jati, 2013). Prinsip pengelolaa lahan pertanian berbasis multifungsi dengan memadukan pertanian dan peternakan dapat berjalan dengan baik apabila didukung oleh kebijakan dan komitmen masyarakat untuk meningkatkan kesejahteraan sosial ekonomi mereka dengan meilbatkan stakeholder yang terkait (Custance, dkk: 2015)

Salah satu model pengembangan desa dapat melalui program integrated farming yaitu sistem yang memadukan komponen pertanian dengan peternakan. Selain itu, integrated farming juga dapat melalui pertanian organik yang dapat menjaga kelestarian lingkungan serta mempunyai peran penting dalam mengubah pola pengembangan pertanian dan dapat meningkatkan produksi pertanian yang berkelanjutan (Nazeerudin, 2013). Metode yang digunakan agar program integrated farming system 
berkelanjutan yaitu dengan pembentukan kelompok tani dan kelompok ternak, rekonstruksi dan optimalisasi karang taruna. Selain itu, pengelolaan potensi sumber daya alam juga menjadi focus pemberdayaan agar dapat meningkatkan perekonomian masyarakat dan menciptakan kawasan agrowisata yang berintegrasi dengan program pertanian terpadu yang ramah lingkungan. Hal ini dilakukan agar masyarakat mengetahui besarnya sumber daya alam yang dimiliki sehingga mereka mampu mengelolanya dengan baik dan meningkatkan perekonomian masyarakat (Zakariah, 2016).

Program integrated farming ini juga diterapkan di Desa Asinan Kecamatan Bawen Kabupaten Semarang yang dikenal sebagai desa yang memiliki potensi alam berupa lahan pertanian yang luas dan dekat dengan Rawa Pening. Sebagian besar lahan sawah adalah pemerintah Desa Asinan atau bengkok desa, sehingga para petani bekerja sebagai penggarap. Mata pencaharian masyarakat Asinan rata-rata adalah sebagai buruh tani. Di Desa Asinan petani penggarap tidak memiliki kedaulatan pangan, karena mereka tidak menikmati padi yang ditanam dan hasil panennya sendiri. Petani menjual langsung kepada penebas dalam bentuk gabah basah yang masih ada disawah.

Dalam rangka pengembangan pertanian di Desa Asinan dan keinginan untuk mengembalikan kondisi lahan sawah yang tercemar oleh bahan-bahan kimia, Bank Indonesia Jawa Tengah sebagai BUMN menggagas sebuah model community development melalui program integrated ecofarming untuk diterapkan di Desa Asinan. Program ini menggabungkan pertanian dengan peternakan dan untuk memperbaiki tanah pada lahan sawah yang terkena residu kimia, perbaikan pada lingkungan dan dapat meningkatkan kualitas hasil panen yang sehat terbebas dari kimia. Untuk mendukung program ini, maka dibentuk sebuah kelompok tani yang diberi nama "Konco Tani Organik".

Seperti pada beberapa program sebelumnya, pendekatan yang dilakukan oleh Bank Indonesia terhadap masyarakat bersifat akomodatif. Pendekatan tersebut berupa identifikasi kebutuhan berbasis pada community need, mengetahui aspirasi masyarakat baik secara individual maupun secara komunitas, memetakan siapa saja pihak yang harusnya terlibat tetapi sejauh ini dalam pembangunan belum dilibatkan, dan mengetahui progress pergerakan yang berkembang di masyarakat (Skerratt dan Steiner, 2013).

Program integrated ecofarming yang digalakkan di Desa Asinan ini telah berjalan sekitar dua tahun. Aktivitas peberdayaan yang telah dilakukan antara lain pelatihan pembuatan dan penggunaan pupuk organik, pembentukan kelembagaan atau kelompok tani, pemberian modal (dana stimulan), dan pembangunan sarana pertanian organik. Pada awalnya, program ini berjalan dengan lacar karena masih intensifnya pendampingan yang dilakukan oleh Bank Indonesia. Tetapi pada saat ini, program tersebut tidak lagi berjalan dengan lancar karena mengalami beberapa kendala. Kendala utamanya adalah penerimaan masyarakat terhadap program ini yang kurang antusias sebab masyarakat yang 
belum terbiasa menggunakan bahan organik dan belum secara nyata melihat hasil panen dari bahan organik. Selama ini, sebagian besar masyarakat Desa Asinan sudah terbiasa menggunakan bahan kimia, sebab hasil panen yang mereka peroleh lebih banyak. Oleh sebab itu, setelah program ini berakhir, para petani di Desa Asinan kembali memakai pupuk kimawi dalam pertanian mereka. Berdasarkan latar belakang tersebut, tulisan ini bertujuan untuk mengetahui: (1) Pelaksanaan kegiatan program integrated ecofarming di Desa Asinan. (2) Hambatan dalam melaksanakan kegiatan integrated ecofarming di Desa Asinan. (3) Partisipasi masyarakat Desa Asinan dalam kegiatan program integrated ecofarming.

\section{METODE PENELITIAN}

Penelitian ini menggunakan metode kualitatif dengan model deskriptif. Lokasi penelitian berada di Desa Asinan, Kecamatan Bawen, Kabupaten Semarang. Informan utama dalam penelitian ini adalah masyarakat Desa Asinan yang masih menerapkan dan yang pernah menerapkan program integrated ecofarming. Informan pendukung yaitu stakeholder yang terkait seperti Kepala Desa Asinan, ketua gapoktan, kepala PKBM Anugrah Bangsa, dan konsultan dari Bank Indonesia Jawa Tengah. Teknik pengumpulan data menggunakan metode observasi, wawancara dan dokumentasi. Analisis data meliputi pengumpulan data, reduksi data, penyajian data dan penarikan kesimpulan. Penelitian ini menggunakan teori pilihan rasional dari James S. Coleman, konsep partisipasi dan teknik analisis Longwe.

\section{HASIL DAN PEMBAHASAN}

\section{Gambaran Umum Lokasi Penelitian Kondisi Geografis Desa Asinan}

Desa Asinan merupakan desa yang terletak di Kecamatan Bawen, Kabupaten Semarang. Desa Asinan memiliki lahan pertanian yang cukup luas yaitu 134 Ha. Daerah ini mempunyai banyak tumbuhan hijau yang cukup melimpah sehingga ternak yang ada di Desa Asinan pakannya tercukupi. Rawa Pening, sebagai salah satu telaga terbesar di Jawa Tengah, juga berbatasan langsung dengan Desa Asinan dijadikan masyarakat sebagai sumber air untuk mengairi sawah, sehingga hasil pertanian yaitu berupa padi cukup bagus. Kondisi ini dianggap dapat mendukung diterapkannya program integrated ecofarming sebagai bentuk pemberdayan di bidang pertanian. Secara administratif, Desa Asinan terdiri dari 4 Dusun, yaitu Dusun Krajan, Dusun Baan, Dusun Sumurup, Dusun Mangkelang. Pemerintahan di setiap dusun dipimpin oleh seorang Kepala Dusun. Ada 5 Rukun Warga dan 22 Rukun Tetangga. Letak wilayah dan batas Desa Asinan adalah sebelah utara yaitu Kelurahan Bawen, sebelah timur yaitu Desa Polosiri, sebelah selatan yaitu Kecamatan Tuntang dan Rawa Pening dan sebelah barat yaitu Kelurahan Tambakboyo Kecamatan Ambarawa.

\section{Kondisi Demografis Desa Asinan}

Berdasarkan jumlah penduduk menurut umur Desa Asinan sejumlah 4180 jiwa, terdiri dari jenis kelamin laki-laki yaitu 2122 jiwa dan perempuan yaitu 2058 jiwa. 
Berdasarkan tingkat pendidikan penduduk Desa Asinan mempunyai jenjang pendidikan yang berbedabeda, jumlah jenjang yang paling banyak yaitu SD sejumlah 1592 orang dan yang paling sedikit adalah perguruan tinggi sejumlah 117 orang. Berdasarkan mata pencaharian Desa Asinan mayoritas bekerja sebagai petani, namun ada juga yang bekerja sebagai PNS, pegawai swasta, pengusaha, buruh, dan peternak.

\section{Kondisi Sosial Budaya Masyarakat Desa Asinan}

Masyarakat Desa Asinan dalam kehidupannya saling bergotongroyong, rukun, dan masyarakatnya saling berinteraksi satu sama lain. Selain rukun dan ramah dengan warga Asinan sendiri juga menghormati warga lain yang berkunjung ke Desa Asinan. Dari segi berkeyakinan masyarakat Asinan berbeda-beda dari mulai Islam, Katholik, Kristen, Hindu saling membaur, bertoleransi dan menghormati satu sama lain. Masyarakat Desa Asinan mempunyai budaya merti dusun dan kesenian kuda lumping. Budaya merti dusun yaitu salah satu bentuk ritual dari slametan yang kental akan unsurunsur Islam, yang sudah dilakukan turun temurun. Ritual ini bertujuan untuk mengungkapkan rasa syukur kepada Tuhan Yang Maha Esa yang telah memberikan keslamatan, kesejahteraan, dan ketentraman masyarakat.

\section{Karakteristik Pertanian di Desa Asinan}

Karakteristik pertanian yang ada di Desa Asinan antara lain pola pertanian menggunakan pupuk organik dari pupuk kotoran sapi, ada juga yang menggunakan pupuk anorganik, dan menggunakan pupuk campuran yang berasal dari pupuk organik dicampur pupuk anorganik. Lahan sawah irigasi, pengairan sawah berasal dari air sungai ataupun dari Rawa Pening. Sebagian besar petani yang ada di Desa Asinan adalah sebagai penggarap. Lahan sawah di Desa Asinan sebagian besar adalah milik pemerintah desa, sehingga para petani yang tidak mempunyai lahan sendiri menggarap lahan sawah milik pemerintah Desa Asinan. Masih melakukan nilai-nilai tradisional seperti melakukan doa bersama sebelum panen dan syukuran setelah panen.

\section{Profil Program Integrated Ecofarming di Desa Asinan}

Program integrated ecofarming merupakan sebuah kegiatan yang terintegrasi dengan menggabungkan pertanian dan peternakan yang memperhatikan lingkungan. 


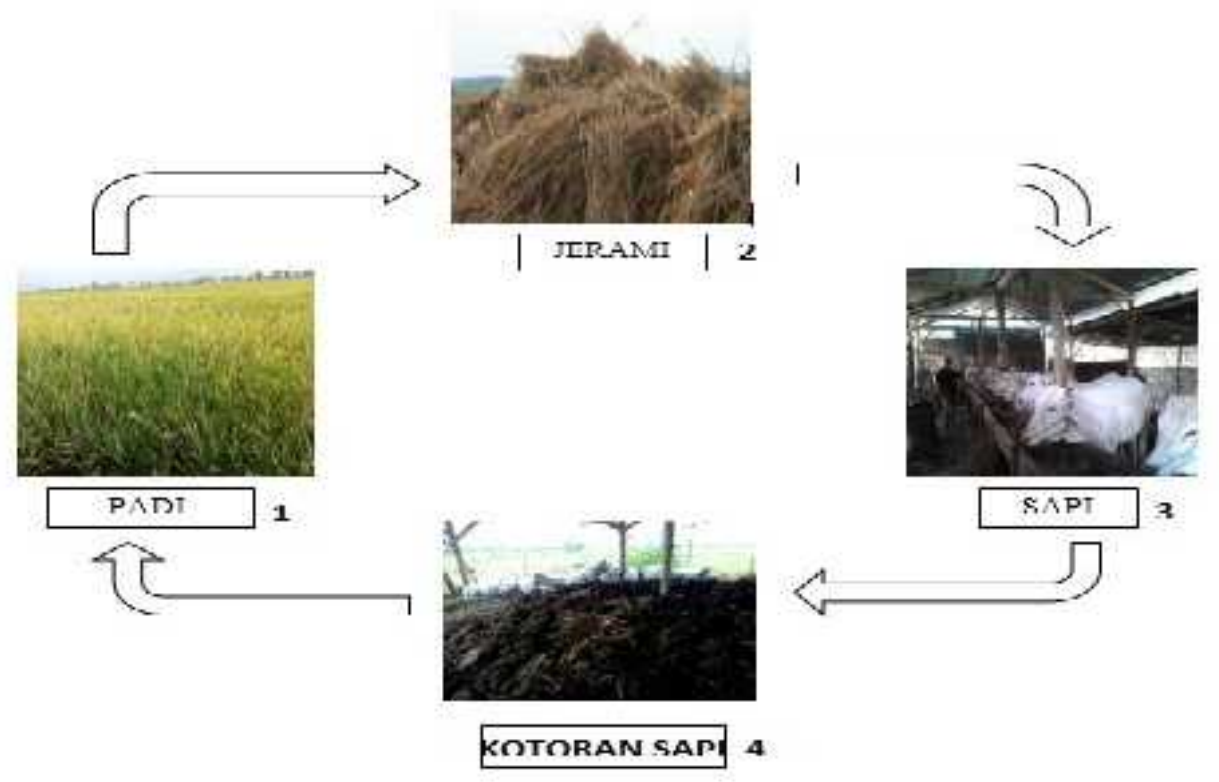

Bagan 1. Siklus keterkaitan pertanian dan peternakan

Sumber: Dokumentasi Peneliti, 2017

Berdasarkan bagan 1 . pertanian dan peternakan saling berkaitan dan terintegrasi satu sama lain. Pada pertanian yang ada di Desa Asinan yaitu tanaman padi menghasilkan jerami. Jerami dapat dimanfaatkan menjadi pakan ternak. Peternakan yang ada di Desa Asinan yaitu ternak sapi yang nantinya kotoran dari sapi baik dari letong maupun urine sapi dimanfaatkan untuk pertanian. Letong sapi dimanfaatkan sebagai pupuk kandang yang digunakan dalam pemupukan padi dan urine sapi yang sudah difermentasi digunakan untuk menyemprot padi.

Program pengembangan integrated ecofarming merupakan program Bank Indonesia untuk mendukung kesinambungan ketersediaan pangan komoditi, meningkatkan akses keuangan kepada sektor pertanian. Bentuk sinergitas dan komitmen para pihak antara lain PKBM Anugrah Bangsa,
Dinas Pertanian, tanaman pangan dan holtikultura Provinsi Jawa Tengah dan PT BRI ungaran sebagai mitra Bank Indonesia.

Lahan sawah di Desa Asinan sebagian milik pemerintah Desa Asinan, bentuknya tanah bengkok yang diberikan kepada perangkat desa sebagai imbalan/gaji mereka dan lahan sawah berupa kas desa yang dapat disewakan. Pada program integrated ecofarming diterapkan pada lahan milik pemerintah desa dan bukan lahan sawah milik umum ataupun perorangan karena penerapan program integrated ecofarming merupakan program pertanian baru yang menggunakan pupuk organik dan para petani tidak berani menerima resiko jika tidak berhasil karena sebelumnya belum pernah menerapkannya. Petani yang menerapkan program integrated ecofarming hanya petani penggarap yang mengolah sawah milik pemerintah Desa Asinan. 


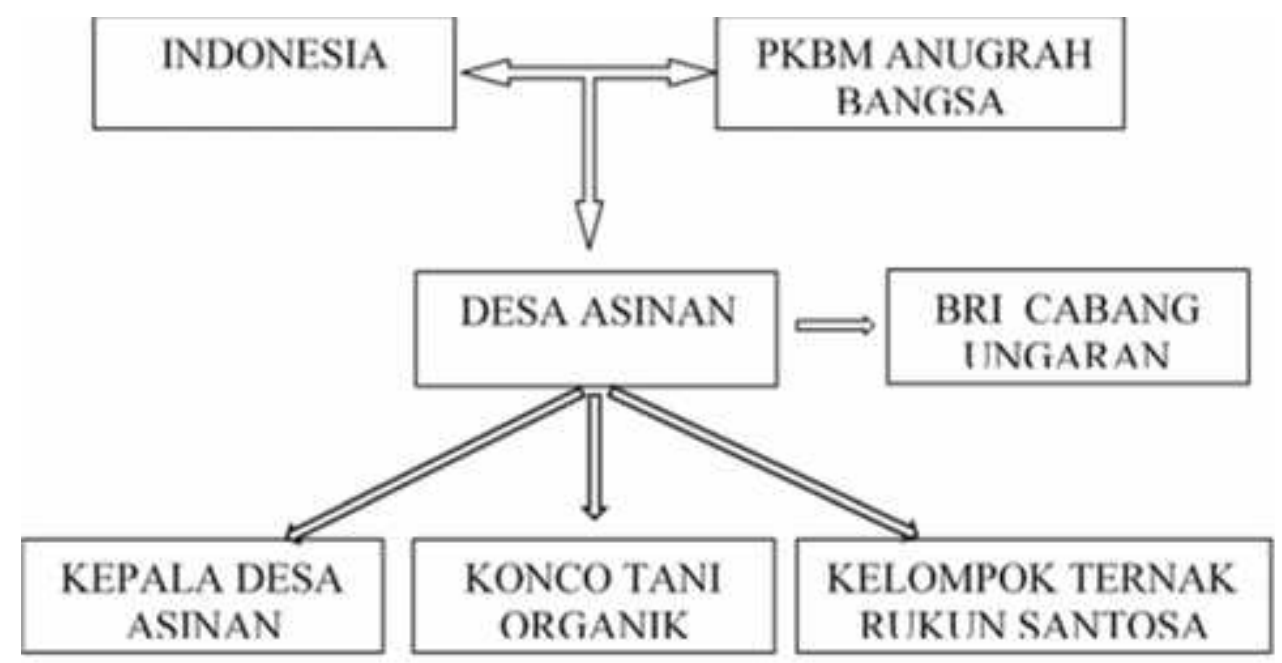

Bagan 2. Bagan stakeholder kemitraan integrated ecofarming Sumber: Hasil Penelitian Farikhah, 2017

Program integrated ecofarming merupakan program Bank Indonesia untuk mendukung kesinambungan ketersediaan pangan komoditas, meningkatkan akses keuangan kepada sektor pertanian. Misi Bank Indonesia melakukan program pertanian terintegrasi yaitu guna meningkatkan daya saing produk unggulan padi organik yang terintegrasi dengan peternakan di Kabupaten Semarang dan memanfaatkan potensi sumberdaya lokal secara optimal dengan memperhatikan kelestarian lingkungan. Bank Indonesia sebagai community development menerapkan program integrated ecofarming yang bekerjasama dengan Bapak Nugroho selaku ketua yayasan PKBM Anugrah Bangsa. Program integrated ecofarming diterapkan di Desa Asinan, untuk menunjang program integrated ecofarming BRI cabang Ungaran memberikan dana pinjaman kredit kepada petani dan peternak dengan bunga $6 \%$. Dalam penerapan program tersebut Bank Indonesia melakukan FGD dengan Kepala Desa Asinan dan kemudian dibentuk kelompok tani yang bernama Konco Tani Organik dan Kelompok ternak bernama Rukun Santosa.

\section{Pelaksanaan Program Integrated Ecofarming di Desa Asinan}

\section{Focus Group Discussion (FGD)}

Pelaksanaan

program integrated ecofarming diawali dengan kegiatan Focus Group Discussion (FGD) yaitu pada tanggal 9 Januari 2014. Tujuan dari FGD tersebut yaitu untuk menggali informasi melalui Kepala Desa. Informasi yang digali mengenai peluang dan hambatan dalam pertanian di Desa Asinan. Disamping melakukan FGD dengan Kepala Desa, Bank Indonesia wilayah Jawa Tengah melakukan pertemuan/identifikasi dengan masyarakat yang meliputi petani dan peternak.

\section{Sosialisasi Pelatihan Pembuatan Pupuk Organik dan Pertanian Padi Organik}

Dalam pelaksanaan program
integrated ecofarming dilakukan


sosialisasi dan pelatihan pembuatan pupuk organik dan pertanian padi organik. Kegiatan sosialisasi dalam program integrated ecofarming tidak hanya tentang pertanian organik dan pelatihan pembuatan pupuk organik tetapi juga ada sosialisasi mengenai kredit KPPE oleh PT BRI Cabang Ungaran. Sosialisasi tersebut ditujukan untuk petani dan peternak. Kerjasama Bank Indonesia JATENG dan BRI Cabang Ungaran memberikan pinjaman dan dana talangan kepada petani ketika pasca panen dan pengembangan peternak.

\section{Pemberian Bantuan dari Bank Indonesia Wilayah Jawa Tengah}

Pemberian Bantuan dari Bank Indonesia wilayah Jawa Tengah meliputi ricemill, gudang penyimpanan padi, dua buah hand traktor untuk membajak sawah, sprayer untuk menyemprot padi, blower digunakan untuk perontok padi saat panen, embung tempat filter air karena pertanian padi organik pengairannya tidak boleh tercemar oleh bahan kimia, pembangunan saung di sekitar sawah untuk pertemuan atau perkumpulan kelompok tani jika ada kegiatan. Selain bantuan sarana dan prasarana, perwakilan petani dan peternak diajak studi banding ke luar kota.

Skema pemberian bantuan oleh dunia perbankan pada masyarakat merupakan salah satu bentuk tanggung jawab perusahaan yang bertujuan untuk membantu meningkatkan kesejahteraan masyarakat. Program ini merupakan bentuk akomoasi baru sebab selama ini dua unsur tersebut ada pada posisi superior (Perbankan) dan inferior (masyarakat desa). Relasi yang terbangun selama ini adalah relasi yang tidak seimbang. Melalui program ini, relasi dominasi mulai dikurangi dan lebih mengarah pada relasi partnership. Pengelolaan pertanian semacam ini sudah mencoba menghubungkan aras dari hulu ke hilir dan mengintegrasikan sektor pertanian dan industri yang selama ini seperti musuh (Livesey, dkk: 2009).

\section{Implementasi Program Integrated Ecofarming}

Implementasi

program integrated ecofarming dimulai pada tahun 2014 dengan dilakukan sosialisasi pertanian dan pembuatan pupuk organik, sosialisasi dari BRI ungaran mengenai dana pinjaman kepada petani dan peternak dan melakukan studi banding ke luar kota.

"Untuk penanaman pertama padi organik dilakukan di lahan sawah bengkok saya, lahan yang digunakan sejumlah 10 hektar dengan hasil panen 1 hektarnya sekitar 5 ton, tonase nya menurun dari biasanya yang pakai kimia bisa mencapai 6-7 ton per hektar tapi untuk panen berikutnya mengalami sedikit peningkatan" (hasil wawancara dengan Bapak Lilik pada tanggal 21 Juli 2017).

Pada panen pertama kualitas dari produk beras organik kurang begitu bagus karena dalam masa pemulihan dari bahan kimia ke organik. Pada masa tanam kedua di tahun 2015 dilakukan pertanian padi organik kembali, pada masa tanam kedua bertepatan dengan musim kemarau sehingga dalam rangka irigasi ke sawah agak terkendala suplai air, untuk kualitas dari hasil panen mulai bagus namun kuantitas hasil panen menyusut. 2015 
persiapan untuk memulai penanaman padi organik. Tahun 2016 hasil panen padi organik kemudian diberi brand "Beras Total Organik Lesung Pulen Rawa Pening”. Memasuki tahun 2017 Bank Indonesia sudah selesai dalam pendampingan dengan Desa Asinan. Pertanian padi yang semula menggunakan total organik pada saat ini dicampur dengan menggunakan pupuk anorganik. Kegiatan pertanian padi mulai dari persiapan media tanam, pemilihan bibit, persemaian, penanaman, perawatan lahan, pencegahan hama dan penyakit, dan pemanenan. Kegiatan peternakan yang menghasilkan kotoran sapi nantinya digunakan untuk pemupukan pertanian.

Program pengembangan masyarakat pedesaan semacam ini merupakan salah satu bagian dari konsep pembangunan masyarakat pedesaaan yang disebut model microsphere smart specialization. Dalam model ini, masyarakat desa diminta mengembangkan dan mengintegrasikan semua potensi yang sudah ada untuk meningkatkan produktifitas dan kesejahteraan ekonominya dengan memperhatikan aspek lingkungan (Talbot, 2016).

\section{Hambatan dalam Melaksanakan Kegiatan Integrated Ecofarming di Desa Asinan}

\section{Pola Pemanfaatan dan Penguasaan Lahan}

Sebagian besar lahan sawah merupakan milik pemerintah Desa Asinan atau bengkok desa. Sehingga petani di Desa Asinan menggarap sawahnya maro dengan pemilik sawah tersebut. Selain sistem maro petani di Desa Asinan yang tidak mempunyai sawah pribadi menggunakan sistem sewa tanah atau sewah lelang. Sistem lelang biasanya dibatasi dengan waktu yaitu satu tahun.

\section{Kondisi Musim}

Ketika musim kemarau untuk ketersediaan air irigasi kurang untuk mengairi sawah. Para petani mengandalkan sumber mata air di sekitar sawah dan air sumur. Terkadang air Rawa Pening tidak cukup untuk mengairi lahan sawah di Desa Asinan Sementara pada musim penghujan, lahan sawah yang dekat dengan Rawa Pening tidak bisa ditanami padi karena sawah tenggelam.

\section{Kurangnya Pasokan Pupuk Organik}

Jumlah ternak di Desa Asinan pada saat ini berkurang hal tersebut mengakibatkan pasokan pupuk sapi juga sedikit. Lahan sawah di Desa Asinan cukup luas, untuk itu membutuhkan pupuk kandang dengan jumlah banyak. Dalam melakukan pertanian padi organik membutuhkan banyak pupuk organik seperti pupuk bokasi letong sapi yang difermentasi dan ditambahkan MA-11. Pupuk MA-11 belum dipasarkan secara umum sehingga para petani agak kesulitan mendapatkannya dan dirasa mahal harganya oleh para petani.

\section{Kebiasaan Petani}

Para petani dalam menggarap sawahnya dari dahulu sudah terbiasa menggunakan pupuk kimia. Sehingga ketika dilakukan perubahan untuk berganti menjadi organik para petani tidak mudah dirubah pola pikirnya. Para petani di Desa Asinan rata-rata sudah berusia tua, ketika ada suatu 
kegiatan yang belun terbiasa dan baru dilakukannya mereka kurang berantusias.

Mengubah kebiasaan bukanlah perkara yang mudah. Perubahan cara memelihara tanaman yang awalnya dengan mudahnya menggunakan pupuk kimia akan menndapatkan hasil maksimal harus diubah ke pupuk organik yang membutuhkan proses dan waktu yang cukup lama membuat para petani tidak sabar. Kondisi ini merupakan salah satu hambatan terbesar dalam pelaksanaan program dan membutuhkan waktu yang cukup lama. Banyak gerakan kembali ke organik dalam menjalankan industri pertanian masih belum menunjukkan hasil yang maksimal (Sikavica dan Pozner, 2013).

\section{Pemanfaatan Sarana dan Prasarana Pertanian}

Pemberian fasililitas dari Bank Indonesia sekarang kurang dimanfaatkan dengan baik. Hal tersebut dibuktikan dengan kondisi sarana dan prasarana tidak terawat dan jarang digunakan. Seperti saung untuk pertemuan di sekitar sawah yang roboh, gudang penyimpanan padi terlihat jarang dibersihkan, embung untuk filter air terlihat keruh.

\section{Pemasaran Produk}

Kegiatan integrated ecofarming menghasilkan produk yaitu berupa Beras Organik Lesung Pulen Rawa Pening. Produk Beras tersebut pernah dipasarkan di Koperasi Bank Indonesia, Koperasi PKBM Anugrah Bangsa dan kepada toko-toko yang memesannya. Namun untuk pemasaran Beras Organik Lesung Pulen Rawa Pening belum bisa dipasarkan secara luas dan swalayan dan toko-toko di seluruh indonesia dikarenakan belum memiliki sertifikat beras organik.

Kesungguhan dan komitmen pemerintah untuk mengembangkan perekonomian lokal berbasis pada potensi masyarakat akan berpengaruh terhadap keberhasilan program. Perekonomian lokal harus dikelola secara modern agar mampu bersaing dengan perekonomian modern. Kesadaran kritis untuk membangun perekonimoan lokal untuk meningkatkan kesejahteraan masayarakat desa bukanlah persoalan yang sederhana. Oleh karena itu keterlibatan semua stakeholder sangat dibutuhkan peran dan kontribusinya (Leach, 2013).

\section{Partisipasi Masyarakat Desa Asinan dalam Kegiatan Program Integrated Ecofarming}

\section{Partisipasi Masyarakat dalam Pengambilan Keputusan}

Dalam pengambilan keputusan, pihak-pihak yang terlibat dalam program integrated ecofarming yaitu perwakilan dari Bank Indonesia wilayah Jawa Tengah dan Kepala Desa Asinan. Pihak Bank BI wilayah Jawa Tengah berkunjung ke Desa Asinan menemui bapak kepala desa untuk melakukan Focus Group Discussion. Setelah FGD masyarakat yang terdiri dari petani dan peternak dilibatkan dalam pertemuan dengan BI wilayah Jawa Tengah dalam rangka pengenalan dan akan adanya program pertanian padi organik yang diintegrasikan dengan peternakan. Petani di Desa Asinan mayoritas adalah petani penggarap, sehingga dalam pengambilan keputusan 
dimusyawarahkan antara petani penggarap dengan pemilik sawah.

\section{Partisipasi Masyarakat dalam Pelaksanaan Integrated Ecofarming}

Keterlibatan masyarakat dalam pelaksanaan kegiatan integrated ecofarming yaitu mengikuti program pelatihan pertanian organik dan pembuatan pupuk organik bokashi dan biofarm dan mengikuti sosialisasi dari PT BRI cabang Ungaran dalam rangka peminjaman dana untuk petani dan peternak di Desa Asinan. Dari perwakilan masyarakat yaitu petani dan peternak melakukan studi banding ke luar kota. Program integrated ecofarming dilakukan dengan pembuatan pupuk organik kemudian penananaman padi organik oleh petani di Desa Asinan di lahan sawah pak lurah.

"saya dulu ikut sosialisasi dan pelatihan pembuatan pupuk, studi banding juga ke luar kota Mbak diajak BI. Dulu saya nggarap sawahnya pak lurah memakai pupuk organik" (Wawancara dengan Bapak Maryadi pada tanggal selasa 18 juli 2017).

Namun mulai tahun 2017, para petani berpartisipasi dalam pertanian padi organik menurun. Mereka pada saat ini menggunakan pupuk kimia atau campuran dari bahan kimia dan organik. Program pertanian padi organik bagi para petani kurang menjual dipasaran akhirnya para petani beralih ke pupuk anorganik kembali.

\section{Partisipasi Masyarakat dalam Pengambilan Manfaat}

\begin{tabular}{|c|c|}
\hline & pel \\
\hline $\begin{array}{l}\text { ecofarming } \\
\text { memberikan }\end{array}$ & $\begin{array}{l}\text { Bank } \\
\text { fasilitas }\end{array}$ \\
\hline
\end{tabular}

menunjang kegiatan pertanian. Masyarakat Desa Asinan cukup antusias ketika sarana dan prasarana dalam menunjang program integrated ecofarming tercukupi. Dalam hal ini masyarakat Desa Asinan merasakan manfaat dengan adanya fasilitas yang diberikan oleh Bank Indonesia. Selain itu, masyarakat diberikan pelatihanpelatihan seperti pertanian padi organik dan pembuatan pupuk organik bokashi dan biofarm.

\section{Partisipasi Masyarakat dalam Evaluasi}

Partisipasi masyarakat dalam evaluasi melibatkan pihak yang bersangkutan seperti Bank Indonesia, Kepala Desa Asinan, petani dan peternak. Kegiatan evaluasi ini dilakukan untuk mengetahui bagaimana pelaksanaan program integrated ecofarming yang berjalan di Desa Asinan. Kegiatan integrated ecofarming dilakukan dengan monitoring oleh Bank Indonesia kemudian dilakukan musyawarah bersama.

Untuk memperkuat analisis aspek partisipasi petani, penulis menggunakan Teknik Analisis Longwe (Sara Hlupekile Longwe) atau Kriteria Pembangunan Perempuan adalah suatu teknik analisis yang dikembangkan sebagai metode pemberdayaan perempuan dengan lima kriteria analisis. Dalam program integrated ecofarming di Desa Asinan termasuk dalam tahap kesejahteraan karena tingkat partisipasi masyarakat masih rendah, dibuktikan dengan program tersebut hanya berjalan selama dua tahun dan pada saat ini tidak berkelanjutan karena belum ada kesadaran kritis dari masyarakat. Program integrated ecofarming 
menggunakan pupuk organik yang membutuhkan banyak biaya sedangkan petani di desa Asinan sebagian besar adalah petani penggarap. Tidak dipungkiri para petani penggarap mengedepankan segi ekonomi dan berorientasi pada profit untuk memenuhi kebutuhan hidup mereka. Pada saat ini para petani memilih kembali menggunakan pertanian anorganik adalah sebuah pilihan rasional karena mereka mempertimbangkan aspek kesejahteraan untuk melangsungkan kebutuhan mereka.

\section{PENUTUP}

Berdasarkan hasil penelitian dan pembahasan dari penelitian ini dapat disimpulkan sebagai berikut:

Dalam pelaksanaan program integrated ecofarming di Desa Asinan dapat dikatakan bahwa program tersebut gagal karena tidak berkelanjutan. Kegiatan integrated ecofarming berjalan selama dua tahun dan para petani pada saat ini kembali lagi menggunakan pupuk anorganik. Program integrated ecofarming di Desa Asinan pada tahap pemasaran belum dimaksimalkan dan belum adanya kesadaran kritis dari masyarakat.

Terdapat beberapa hambatan dalam pelaksanaan program integrated ecofarming antara lain pola pemanfaatan dan pengusaan lahan para petani di Desa Asinan menggunakan sistem maro dan sistem sewa. Pada musim kemarau kekurangan air sedangkan pada musim hujan sawah di dekat Rawa Pening terendam air sehingga tidak dapat ditanami padi. Kurangnya pasokan pupuk organik, kebiasaan petani dan maindset petani yang tidak mudah dirubah karena terbiasa menggunakan pupuk anorganik. Sarana dan prasarana yang kurang dimaksimalkan. Pemasaran produk yang susah karena beras belum tersertifikasi organik. Terkait dengan teori pilihan rasional James $\mathrm{S}$. Coleman, petani mempunyai pilihan untuk melaksanakan pertanian, karena dalam pelaksanaan integrated ecofarming terdapat beberapa hambatan yang membuat petani pada saat ini memilih pilihan untuk kembali dengan pertanian anorganik kembali. Partisipasi masyarakat dalam program integrated ecofarming meliputi dari partisipasi pengambilan keputusan, partisipasi dalam pelaksanaan, pengambilan manfaat, partisipasi dalam evaluasi serta dalam analisis longwe partisipasi masyarakat Desa Asinan termasuk ke dalam kriteria kesejahteraan.

\section{UCAPAN TERIMAKASIH}

Penulis mengucapkan terimakasih kepada Masyarakat Desa Asinan yang telah membantu dan menfasilitasi selama penelitian, serta membantu penulis dalam memperoleh data di lapangan. Kepala Desa Asinan yang telah memberikan ijin untuk penelitian. Semua pihak yang telah membantu dalam penelitian, yang tidak dapat penulis sebutkan satupersatu.

\section{DAFTAR PUSTAKA}

Arquitt and Cornwell. 2007. MicroMacro Linking Using System Dynamics Modeling: An Examination of Eco-Labeling Effects for Farmed Shrimp. Journal of Macromarketing, Vol. 27 No. 3, September 2007 243255. 
Badan Pusat Statistik Kabupaten Semarang. 2016. Kecamatan Bawen dalam Angka 2016. Semarang: Badan Pusat Statistik.

Custance, Walley etc. 2015. Agricultural Multifunctionality And Care Farming: Insight from the UK. South Asian Journal of Business and Management Cases. 4(1) 74-86. Sage Publication.

Dwiningrum, Siti Irene Astuti. 2011. Desentralisasi dan Partisipasi Masyarakat dalam Pendidikan. Yogyakarta: Pustaka Pelajar.

Fatimah, Nurul dan Eli Kismini. 2009. KOPSERINDO (Koperasi Serat Rami Indonesia) Sebuah Industri Pemberdayaan Masyarakat Desa (Studi Kasus di Desa Pecekelan Kecamatan Sapuran Kabupaten Wonosobo). Jurnal Forum Ilmu Sosial. Vol 36, No 1.

Gandi, Grita Gusti, dkk. 2017. Jaringan Sosial Petani dalam Sistem Ijon Pada Pertanian di Desa Pagenteran Kecamatan Pulosari Kabupaten Pemalang. Jornal Solidarity. Vol 6, No 1.

Jati, Dian Purnomo, dkk. 2013. Model Pengembangan Desa Inovatif Desa Kalisari Kabupaten Banyumas. Journal\&Proceeding Feb UNSOED. Vol.3, No.1.

Luthfi, Asma. 2010. Akses dan Kontrol Perempuan Petani Penggarap Pada Lahan Pertanian PTPN IX Kebun Merbuh. Jurnal Komunitas. Vol 2, No.2.

2013. Problematika

Pembentukan Kesadaran Kritis pada PNPM-Mandiri Perkotaan (Studi Kasus di Kelurahan Sekaran, Kecamatan
Gunungpati, Kota Semarang). Jurnal Forum Ilmu Sosial. Vol 40, No 1.

Leach, Karen. 2013. Community Economic Development: Localisation, The Key to A Resilient and inclusive local economy? Local Economy. 28(78) 927-931. Sage Publication.

Livesey, etc. 2009. Performing Sustainable Development Through Eco Collaboration; The Ricelands Habitat Partnership. Journal of Business Communication. Volume 46, Number 4, October 2009 423-454.

Nazeerudin. 2013. Participatory Model Approach or Organic Agriculture in Karnataka India. International Journal of Development and Sustainability. Vol.2, No.3.

Skerratt dan Steiner. 2013. Working with Communities-Of-Place: Complexities of Empowerment. Local Economy. 28(3) 320-338. Sage Publication.

Sikavica dan Pozner. 2013. Paradise Sold: Resource Partitioning and the Organic Movement in the US Farming Industry. Organization Studies. 34(56) 623-651. Sage Publication.

Talbot, Steve. 2016. Creating A Smart Rural Economy Through Smart Specialisation: The Microsphere Model. Local Economy. Vol. 31(8) 892919. Sage Publication.

Zakariah, Muhamad Askari. 2016. Optimalisasi Pemberdayaan Masyarakat Desa Melalui Pengembangan Ekonomi dan Agrowisata Berbasis Integratred Farming System di Kecamatan Mowewe Kabupaten Kolaka Timur. Jurnal Ilmiah Al Mawaddah. Vol 11, No.1, hal 31-43. 